\title{
Review of inhaled iloprost for the control of pulmonary artery hypertension in children
}

\author{
Cecile Tissot \\ Maurice Beghetti \\ Pediatric Cardiology Unit, \\ Department of the Child \\ and Adolescent, University \\ Hospital of Geneva, Switzerland
}

Correspondence: Maurice Beghetti Unité de Cardiologie Pédiatrique, Hôpital des Enfants, 6 rue Willy Donzé, $\mathrm{CH}$ - I2I I Genève 14, Switzerland $\mathrm{Tel}+4 \mid 223824580$

Fax +4I 223824546

Email maurice.beghetti@hcuge.ch

\begin{abstract}
In the pediatric population, pulmonary hypertension may present as an acute event in the setting of lung or cardiac pathology or as a chronic disease, mainly as idiopathic pulmonary hypertension or associated with congenital heart disease. Recently, new pharmacologic approaches have demonstrated significant efficacy in the management of adults with pulmonary arterial hypertension; these include intravenous epoprostenol, prostacyclin analogs, endothelin receptor antagonists and phosphodiesterase type 5 inhibitors. The same treatment strategies are currently used in children. There are only few reports of the use of inhaled iloprost in pediatrics, only one of which reported the use of chronic inhaled iloprost in a significant number of children. This report showed that 1) the acute pulmonary vasodilator response to inhaled iloprost is equivalent to that of inhaled nitric oxide; 2) acute inhalation of iloprost can induce bronchoconstriction 3) the addition of inhaled iloprost can reduce the need for intravenous prostanoid therapy in some patients; 4) most children tolerated the combination of inhaled iloprost and endothelin receptor antagonist or phosphodiesterase inhibitors; 5) Several patients had clinical deterioration during chronic inhaled iloprost therapy and required rescue therapy with intravenous prostanoids. In this review we will discuss the role of inhaled iloprost in acute and chronic pulmonary hypertension in children.
\end{abstract}

Keywords: pulmonary hypertension, children, iloprost

\section{Introduction}

In the pediatric population, pulmonary hypertension may present as an acute event in the setting of lung or cardiac disease, for example after cardiopulmonary bypass for correction of congenital heart disease ${ }^{1}$ or associated with acute lung injury. A specific form of pediatric pulmonary hypertension is persistent pulmonary hypertension of the newborn. But pulmonary hypertension also presents as a chronic disease in children., ${ }^{2,3}$

Chronic pulmonary arterial hypertension is a rare and complex disease characterized by vasoconstriction and progressive remodeling of the pulmonary arterial wall leading to right ventricular failure and death. ${ }^{4}$ The pathologic features are similar in children and in adults but the spectrum of associated conditions, clinical presentation and factors influencing survival differ slightly. ${ }^{2,5,6}$ The different etiologies are all included in the revised classification of Venice, which was first mainly produced for adult patients. $^{7}$ The most common etiologies in children after the immediate neonatal period are idiopathic, familial or associated with congenital heart disease.

Historically, pulmonary arterial hypertension carried a dismal prognosis in children less than 16 years with a median survival of 0.8 years compared to 2.8 years in adults. ${ }^{6}$ The role of endothelial dysfunction and the abnormal balance of vasodilator-antimitotic (prostacyclin and nitric oxide) versus vasoconstrictor-promitotic (endothelin-1) substances shown in adults ${ }^{4}$ are also true for the pediatric population. We have now moved from the belief of pulmonary arterial hypertension as a process driven 
by vasoconstriction only, to a concept of a disease also characterized by proliferation and remodeling.

Recently, new pharmacologic approaches have demonstrated significant efficacy in the management of adults with pulmonary arterial hypertension (PAH); these include intravenous eproprostenol, ${ }^{8}$ prostacyclin analogs delivered subcutaneously (treprostinil ${ }^{9}$ ) or by inhalation $\left(\right.$ iloprost ${ }^{10}$ ), endothelin receptor antagonists (bosentan ${ }^{11,12)}$ and $\operatorname{ambrisen} \tan ^{13}$ ) and phosphodiesterase type 5 inhibitors (sildenafil ${ }^{14}$ ). The same treatment strategies are currently used in children. ${ }^{2,6,15}$ In the late 1990s, the development of chronic vasodilator therapy including calcium channel blockers for acute responders to vasodilator testing and continuous intravenous epoprostenol for non-responders has dramatically improved the outcome of children, with some children surviving more than 10 years after diagnosis. ${ }^{16}$

However, the use of continuous intravenous epoprostenol ${ }^{17}$ in children, even if clearly efficacious, remains a difficult approach both for the child and the parents. The need for a permanent central line and pump and its associated risks of infection, thrombosis and dysfunction lead to the development of other delivery approach. In this review, we will discuss the rationale of using inhaled iloprost in acute and chronic pulmonary hypertension in children as well as the potential benefit and problems of this therapy.

\section{Iloprost}

Prostacyclin is a naturally occurring prostaglandin described more than 20 years ago to be a potent antiaggregatory and vasodilator agent. ${ }^{18}$ Prostacyclin is primarily produced by the endothelial cells of the vascular intima and acts through a specific receptor-mediated activation of membrane-bound adenylate cyclase and a consequent increase in intracellular cyclic adenosine monophosphate. ${ }^{19}$

Iloprost is a stable prostacyclin analog, pharmacologically similar to epoprostenol, with vasodilatory, vascular remodeling and platelet inhibitory properties, but is a more stable compound, with an elimination half-life of 20 to 30 minutes. ${ }^{20}$ Iloprost exerts its effects via prostacyclin receptors and promote similar mechanisms to epoprostenol. The biological effects of prostacyclin are indeed mediated by binding to a group of receptors. The receptors for prostanoids are classified into DP, IP, EP, FP and TP. ${ }^{21}$ There are some differences, as different analogs seem to activate different subgroups of receptors. Iloprost is thought to bind to IP and EP3 receptors, but the final intracellular effect as mentioned is essentially through the increase of cAMP via stimulation of guanylate cyclase. The transduced biological effects are vasodilation, inhibition of platelet activation and aggregation, inhibition of leukocytes activation, and adhesion (anti-inflammatory effects) and antiproliferation. Iloprost has also shown some de-remodeling effect in animal studies. ${ }^{22,23}$

There is extensive experience with its intravenous use in different indications including thromboarteritis obliterans ${ }^{24}$ or Raynaud phenomenon. ${ }^{25}$ In general, the doses used are in the range of 1 to $10 \mathrm{ng} / \mathrm{kg} / \mathrm{min}$ compared to doses ranging from 10 to $50 \mu \mathrm{g} / \mathrm{kg} / \mathrm{min}$ for epoprostenol, but the dosages may fluctuate.

The main problem related to the intravenous use is the lack of selectivity for the pulmonary vascular bed and therefore the potential risk of systemic hypotension. To overcome the systemic side effects, the inhaled route has been used to obtain pulmonary selectivity similarly to inhaled nitric oxide. The distance between the alveoli and the smooth muscle cell is $10 \mu \mathrm{m}$ at the most, allowing for easy transfer of the inhaled drug. The real barrier to uptake is the vascular adventitia itself. A prerequisite is to obtain particles that can reach the alveoli, and for this purpose the droplet size should range between 2.5 and $5 \mu \mathrm{m}$. When administered by inhalation iloprost is selective for the pulmonary vasculature, inducing a decrease in pulmonary vascular pressure with no or minor effects on the systemic circulation. Moreover, it can be delivered to only ventilated regions, avoiding the potential increase of intrapulmonary shunts by dilating vessels in nonventilated areas, as seen with intravenous administration. This preferential delivery to well-ventilated regions areas improves ventilation perfusion mismatch. ${ }^{26}$

When prostacyclins are administered intravenously a tachyphylaxis phenomenon may appear requiring permanent dose escalation. This may be explained by desensitization of the IP receptor and/or a saturation of the transporter system. ${ }^{27,28}$ Research has shown that this leads to complete loss of vasodilatory response to prostanoids, and this should be kept in mind when using prostanoids treatment. This phenomenon may indeed explain the failure of the drug in some patients as well as the need of dose escalation.

\section{Adult use of inhaled iloprost}

Until recently, chronic treatment with prostacyclin analogs in adults has required intravenous or subcutaneous administration, with each approach limited by problems such as line infections, thrombosis, or site pain. Previous studies of inhaled iloprost have been performed primarily in adult patients. ${ }^{29,30}$ In one large multicenter, randomized, placebo-controlled trial of iloprost therapy for 3 months, more patients demonstrated the combined endpoint of at 
least a $10 \%$ improvement in the 6 minute walk distance and improvement in NYHA functional class (17\% vs 5\%; $\mathrm{p}<0.01$ ), and no deterioration or death. ${ }^{10}$ This trial included 203 patients with idiopathic pulmonary hypertension, or $\mathrm{PAH}$ occurring in association with appetite suppressant use, inoperable chronic thromboembolic pulmonary hypertension, and connective tissue disease. The 6 minute walk distance increased by $36 \mathrm{~m}$ in the iloprost-treated patients, and increased by $59 \mathrm{~m}$ in patients with idiopathic pulmonary hypertension. ${ }^{10}$

Opitz et al described the long term clinical efficacy of inhaled iloprost as first-line monotherapy in patients with idiopathic PAH. In this study, only a minority of patients could be stabilized with inhaled iloprost monotherapy during a follow-up of up to 5 years. The authors concluded that chronic iloprost appears to have a limited role in the era of multiple treatment options.

Most recently, inhaled iloprost has been studied in patients who remain symptomatic (NYHA functional class III or IV) while on stable bosentan therapy for at least 3 months. ${ }^{31}$ In this multicenter, randomized controlled trial, 67 patients with PAH (94\% NYHA functional class III, mean baseline 6 minute walk distance $355 \mathrm{~m}$ ) were randomized to receive inhaled iloprost or placebo. After 12 weeks, post-inhalation 6 minute walk distance improved by $30 \mathrm{~m}$ in the iloprost group and $4 \mathrm{~m}$ in the placebo group, for a placebo-adjusted difference of $+26 \mathrm{~m}(\mathrm{p}=0.051)$. There were also improvements in NYHA functional class ( $\mathrm{p}=0.002)$, time to clinical worsening $(\mathrm{p}=0.022)$ and post-inhalation mean pulmonary arterial pressure $(\mathrm{p}<0.001)$, and pulmonary vascular resistance $\mathrm{p}<0.001)$. When assessing carefully these results, one can notice that the predefined significance on the primary endpoint was not achieved. Moreover the clinical significance of an increase of $26 \mathrm{~m}$ should be questioned. However, this study showed that combination therapy of inhaled iloprost appeared to be safe and well tolerated.

Even if strong scientific data are not available, clinical experience and current study results may lead to the conclusion that inhaled iloprost may not be ideal for first-line monotherapy in chronic pulmonary hypertension. Its use in combination with other targeted therapy remains however of interest as there may be some synergism, for example with phosphodiesterase inhibitors (ie, sildenafil), assuming that the latter may keep the levels of cAMP elevated in the cell and prolong or augment the effects of iloprost. ${ }^{32-35}$ This clearly requires further clinical studies.

Inhaled iloprost was approved by the FDA in 2004 for functional class III and IV PAH, and in 2005 the indication was broadened to include add-on therapy for patients who remain symptomatic despite oral therapy with other agents.

When used chronically, inhaled iloprost may result in some side effects the most frequently reported in the adult population being flush, jaw pain, pain in lower extremities, headaches and diarrhea.

Although extensively studied in adults with PAH, less is known about the relative efficacy of inhaled iloprost in children and experience has been limited, especially for prolonged therapy. We will now review this experience.

\section{Dose and delivery in pediatrics}

As mentioned, studies to evaluate delivery system and potential doses have essentially been performed in adults and there is clearly a lack of studies in the pediatric population. These are needed urgently. But as this disease is serious and life threatening, pediatricians have tried to extrapolate from adult studies on how to use inhaled iloprost in children.

Iloprost is available as single-use vials containing $10 \mu \mathrm{g} / \mathrm{mL}$ either in a $1 \mathrm{~mL}$ or $2 \mathrm{~mL}$ aqueous solution. Indications approved are patients with idiopathic PAH NYHA class III in Europe (EMEA) and patients with PAH (group 1 of Venice classification) in NYHA class III and IV in the United States (FDA). For pediatrics, it is mentioned safety and efficacy has not been established.

The recommended doses are 2.5 or $5 \mu \mathrm{g}$ of inhaled iloprost starting with the low dose followed by the $5 \mu \mathrm{g}$ for the second inhalation. Iloprost should not be taken less than 6 times per day and up to 9 times are allowed. The maximal doses evaluated in trials were $45 \mu \mathrm{g}$ per day.

Again no mention for specific dosages is available for pediatrics, as the drug is not approved for this population.

With regards to delivery devices, it is allowed or possible to use different devices providing that the droplets size is between 2.5 and $5 \mu \mathrm{m}$. In Europe, 4 devices are recommended for use: Venta-Neb ${ }^{\mathrm{TM}}$ (Nebutec Company, Elsenfeld, Germany), Halolite ${ }^{\mathrm{TM}}$, Pro-Dose ${ }^{\mathrm{TM}}$ AAD $^{\mathrm{TM}}$ System, and $\mathrm{I}_{-\mathrm{Neb}^{\mathrm{TM}}} \mathrm{AAD}^{\mathrm{TM}}$ System (all devices from Respironics Inc, Murrysville PA, USA). In the United States two devices are allowed the I-Neb ${ }^{\mathrm{TM}} \mathrm{ADD}^{\mathrm{TM}}$ System and the Pro-Dose ${ }^{\mathrm{TM}} \mathrm{AAD}^{\mathrm{TM}}$ System. Again no devices has been specifically tested in children

When the drug is applied to children older than 12 years and close to an adult weight an adult dose can be used; in smaller and younger patients physicians need to extrapolate the dose to be used in children. For delivery devices the rule of droplets size between 2.5 and $5 \mu \mathrm{m}$ is true for children also. 
However, depending on the age, clearly inhalation may be more problematic but we must remember that children with asthma or cystic fibrosis learn quite easily how to inhale at a very young age, and therefore inhalation may not be a major problem.

\section{Chronic pulmonary hypertension}

Several case reports reported the use of aerosolized iloprost in children. One of the first clinical reports in a young patient was in 2001. A 5-year-old boy was treated with inhaled iloprost at a daily dose of $24 \mu \mathrm{g}$ (6 times $4 \mu \mathrm{g}$ ). He showed continuous clinical improvement for three years while on therapy and avoided the use of continuous infusion of prostacyclin for this period. No side effects were reported. ${ }^{36}$ The use of inhaled iloprost in combination with bosentan allowed to delaying lung transplantation in an 8-year-old boy. ${ }^{37}$ Aerosolized iloprost was used a bridge to transplantation in young patients with cystic fibrosis. ${ }^{38}$ We can clearly not suggest that inhaled iloprost is beneficial in young patients with cystic fibrosis but this case report raises the possibility of using this drug in patients with increased pulmonary pressure and cystic fibrosis. A study dedicated to this particular group of patients would be of major interest.

There is currently only one study showing the effect of chronic iloprost in a significant number of pediatric patients. ${ }^{39}$ Ivy et al examined the acute and chronic effects of inhaled iloprost in 23 children with idiopathic PAH or PAH associated with congenital heart disease. The dose applied ranged between $2.5 \mu \mathrm{g}$ and $10 \mu \mathrm{g}$ with 4 to 9 inhalations a day for a total daily dose of 3.75 to $50 \mu \mathrm{g}$, depending of the age and weight of the patients. No definite dosing for patient was discussed and no dose-ranging effect evaluation was performed during this study. The results show that 1) the acute pulmonary vasodilator response to inhaled iloprost is equivalent to the effects of inhaled nitric oxide as measured during cardiac catheterization; 2) acute inhalation of iloprost can induce bronchoconstriction in some children, as demonstrated by cough and reductions in $\mathrm{FEV}_{1}$ and $\mathrm{FEF}_{25 \%-75 \%}$ by pulmonary function tests; 3 ) the addition of inhaled iloprost therapy can reduce the need for intravenous prostanoid therapy in some patients; 4) most children tolerated the combination of inhaled iloprost and endothelin receptor antagonist or phosphodiesterase inhibitors. 5) Several patients had clinical deterioration during chronic inhaled iloprost therapy and required rescue therapy with intravenous prostanoids.

\section{Acute pulmonary hypertension}

One of the major advantages of the inhalative approach is its selectivity for the pulmonary vascular bed. This is of major importance when used in acute pulmonary hypertensive crisis with hemodynamic compromise characterized by low systemic pressure and low cardiac output. The minor effect on systemic pressure is here particularly beneficial. Moreover, its intrapulmonary selectivity may improve ventilation/ perfusion mismatch and potentially oxygenation.

Inhaled iloprost was first used in patients with acute respiratory failure and increased pulmonary arterial pressure accompanied by disturbances of gas exchange, ${ }^{40}$ then in acute heart right failure ${ }^{41}$ and later effects were compared with those of inhaled nitric oxide. ${ }^{42}$ All these different pathologies are encountered in pediatrics and thus these approaches have also been reported in children.

Several small studies have shown the potential efficacy of inhaled iloprost in the acute pulmonary hypertension setting in pediatrics such as acute lung injury, post-cardiopulmonary bypass or in persistent pulmonary hypertension of the newborn.

De Luca et al reported two neonates treated with inhaled iloprost for persistent pulmonary hypertension of the neonate, one with diaphragmatic hernia and one associated with an aneurysm of the vein of Galien. ${ }^{43}$ Both patients were refractory to inhaled nitric oxide. Dose administered was $1 \mu \mathrm{g}$ every 4 hours. They showed improvement in oxygenation. Chotigeat et al reported one case of persistent pulmonary hypertension of the neonate that had hypoxia despite high frequency oscillation, inotropic drugs and oral sildenafil. Aerosolized iloprost was given trough the nasotracheal tube and induced significant improvement in oxygenation. ${ }^{44}$ Eifinger et al treated 4 preterm neonates with $2 \mu \mathrm{g} / \mathrm{kg}$ iloprost per dose for a total of 44 to 65 doses in total. Oxygenation improved and echocardiography showed reduction in pulmonary pressure. ${ }^{45}$

We are, however, still facing the same problem with these small case studies as no dose response or dose efficacy has been reported and multiple different dosage are used which does not allow recommendations to be made for dose administration in this population. Moreover these patients were on spontaneous ventilation or intubated and ventilated with different modes of ventilation, which increases the difficulty of assessing the dose delivered to the patient.

Some studies have also presented the use of inhaled iloprost in acute pulmonary hypertension after cardiopulmonary bypass for cardiac repair. Zwissler described the selective pulmonary vasodilatation of inhaled prostacyclin in a newborn after cardiopulmonary bypass. ${ }^{46}$ However, no large scale or randomized study has been performed in theses setting and it would be important to better assess the role of 
this therapy in pediatric acute pulmonary hypertension and compare with the use of inhaled nitric oxide. An important aspect in acute patients is that all information on dosage is available in non-intubated patients and with delivery systems mentioned above; no real dose-finding studies or absorption studies have been conducted in intubated patients. It is not known how much drug is delivered to the patient and how much may be deposited in the nasotracheal tube for example. As such, caution should be the rule particularly in very young patients, and drug delivery in intubated patients should still be considered experimental. Studies should also aim to determine the dose and mode of delivery particularly in intubated patients.

\section{Vasoreactivity testing}

The assessment of pulmonary vascular reactivity plays an essential role in PAH. This is true for all forms of PAH to decide if, potentially, patients can be treated with calcium channel blockers in the so-called responders ${ }^{47}$ and also for PAH associated with congenital heart disease to decide for operability. ${ }^{48} \mathrm{~A}$ landmark study in adults showed that inhaled iloprost can be used for vasoreactivity testing and it was shown to be even more potent than inhaled nitric oxide. ${ }^{49}$ However, it may be of interest to perform a study similar to that of Sitbon to prove that acute effects of inhaled iloprost during acute testing can be translated to long term beneficial effects of calcium channel blockers. We and others have shown that the response to inhaled nitric oxide seems to depend on the degree of pulmonary vascular disease and thus may be helpful in selecting patients for surgery. ${ }^{50,51}$ We have shown that in children with PAH and congenital heart disease, both inhaled nitric oxide and aerosolized iloprost are equally effective in selectively lowering pulmonary vascular resistance, both in the pre- and post-operative period using $25 \mathrm{ng} / \mathrm{kg} / \mathrm{min}$ of iloprost. ${ }^{51}$ Halliloglu showed that both aerosolized and intravenous iloprost significantly decreased in pulmonary pressure but aerosolized iloprost was more selective without decreasing systemic vascular pressure. ${ }^{52}$ Recently, Ivy et al showed that acute administration of inhaled iloprost lowered mean pulmonary artery pressure equivalent to the response to inhaled nitric oxide with oxygen. ${ }^{39}$ In this study the acute effects of inhaled iloprost were also assessed by pulmonary function prior to the initiation of chronic therapy and some patients presented significant airways reactivity.

\section{Summary and conclusion}

Inhaled iloprost has been show to combine efficacy with excellent tolerability and safety in the adult population.
In several case series and case reports, similar results have been described in the pediatric population with more emphasis on acute pulmonary hypertension. The major drawbacks of this therapy remain the need for 6 to 9 inhalations a day, which if difficult in an adult is even more complicated in a very young patient. But this is not the only problem, and specific studies in the pediatric population are required. They should better define the dose for pediatric patients, if the use of the current devices to deliver iloprost in adults is also to be used in young patients. Currently strategies for further improvement that need to be studied in children include the use of controlled-released formulations (iloprost loaded liposomes) which may decrease the number of aerosol inhalations.

The current practice in children suggests that physicians choose first an oral therapy, for practical reasons mainly and, as shown by the report of Ivy, ${ }^{39}$ inhaled iloprost is used as add on therapy because of inadequate response to oral treatment.

Significant data are still lacking and specific studies in pediatric patients are urgently needed.

\section{Disclosures}

Professor Beghetti has served on a advisory boards for Pfizer, Actelion, Bayer-Schering, Encysive, GlaxoSmithKline, INO therapeutics, Eli Lilly and Mondobiotech, and has received lecture fees from Actelion, Encysive and Bayer-Schering.

\section{References}

1. Beghetti M. Congenital heart disease and pulmonary hypertension. Rev Port Cardiol. 2004;23(2):273-281.

2. Haworth SG. The management of pulmonary hypertension in children. Arch Dis Child. 2008;93(7):620-625.

3. Beghetti M. [Pulmonary arterial hypertension in children: new therapeutic approaches]. Ann Fr Anesth Reanim. 2007;26(6):570-575.

4. Humbert M, Sitbon O, Simonneau G. Treatment of pulmonary arterial hypertension. N Engl J Med. 200430;351(14):1425-1436.

5. Rashid A, Ivy D. Severe paediatric pulmonary hypertension: new management strategies. Arch Dis Child. 2005;90(1):92-98.

6. Rosenzweig EB, Barst RJ. Pulmonary arterial hypertension in children: a medical update. Curr Opin Pediatr. 2008;20(3):288-293.

7. Galie N, Torbicki A, Barst R, Dartevelle P, Haworth S, Higenbottam T, et al. Guidelines on diagnosis and treatment of pulmonary arteria hypertension. The Task Force on Diagnosis and Treatment of Pulmonary Arterial Hypertension of the European Society of Cardiology. Eur Heart J. 2004;25(24):2243-2278.

8. Rubin LJ, Mendoza J, Hood M, McGoon M, Barst R, Williams WB, et al. Treatment of primary pulmonary hypertension with continuous intravenous prostacyclin (epoprostenol). Results of a randomized trial. Ann Intern Med. 1990;112(7):485-491.

9. Simonneau G, Barst RJ, Galie N, Naeije R, Rich S, Bourge RC, et al. Continuous subcutaneous infusion of treprostinil, a prostacyclin analogue, in patients with pulmonary hypertension. Am J Respir Crit Care Med. 2002;165:1-5.

10. Olschewski H, Simonneau G, Galie N, Higenbottam T, Naeije R, Rubin LJ, et al. Inhaled iloprost for severe pulmonary hypertension. N Engl J Med. 2002;347(5):322-329. 
11. Channick RN, Simonneau G, Sitbon O, Robbins IM, Frost A, Tapson VF, et al. Effects of the dual endothelin-receptor antagonist bosentan in patients with pulmonary hypertension: a randomised placebo-controlled study. Lancet. 2001;358(9288):1119-1123.

12. Rubin LJ, Badesch DB, Barst RJ, Galie N, Black CM, Keogh A, et al. Bosentan therapy for pulmonary arterial hypertension. $N$ Engl J Med. 2002;346(12):896-903.

13. Galie N, Olschewski H, Oudiz RJ, Torres F, Frost A, Ghofrani HA, et al. Ambrisentan for the treatment of pulmonary arterial hypertension: results of the ambrisentan in pulmonary arterial hypertension, randomized, double-blind, placebo-controlled, multicenter, efficacy (ARIES) study 1 and 2. Circulation. 2008;117(23):3010-3019.

14. Galie N, Ghofrani HA, Torbicki A, Barst RJ, Rubin LJ, Badesch D, et al. Sildenafil citrate therapy for pulmonary arterial hypertension. N Engl J Med. 2005;353(20):2148-2157.

15. Beghetti M. Current treatment options in children with pulmonary arterial hypertension and experiences with oral bosentan. Eur J Clin Invest. 2006;36 Suppl 3:16-24.

16. Yung D, Widlitz AC, Rosenzweig EB, Kerstein D, Maislin G, Barst RJ. Outcomes in children with idiopathic pulmonary arterial hypertension. Circulation. 2004;110(6):660-665.

17. Barst RJ, Maislin G, Fishman AP. Vasodilator therapy for primary pulmonary hypertension in children. Circulation. 19;99(9):1197-1208.

18. Moncada S, Gryglewski R, Bunting S, Vane JR. An enzyme isolated from arteries transforms prostaglandin endoperoxides to an unstable substance that inhibits platelet aggregation. Nature. 1976;263(5579):663-665.

19. Moncada S, Vane JR. Arachidonic acid metabolites and the interactions between platelets and blood-vessel walls. $N$ Engl J Med. 1979;300(20):1142-1147.

20. Grant SM, Goa KL. Iloprost. A review of its pharmacodynamic and pharmacokinetic properties, and therapeutic potential in peripheral vascular disease, myocardial ischaemia and extracorporeal circulation procedures. Drugs. 1992;43(6):889-924.

21. Vane JR, Botting RM. Pharmacodynamic profile of prostacyclin. Am J Cardiol. 1995;75(3):3A-10A.

22. Schermuly RT, Yilmaz H, Ghofrani HA, Woyda K, Pullamsetti S, Schulz A, et al. Inhaled iloprost reverses vascular remodeling in chronic experimental pulmonary hypertension. Am J Respir Crit Care Med. 2005;172(3):358-363.

23. Schermuly RT, Kreisselmeier KP, Ghofrani HA, Samidurai A, Pullamsetti S, Weissmann N, et al. Antiremodeling effects of iloprost and the dual-selective phosphodiesterase 3/4 inhibitor tolafentrine in chronic experimental pulmonary hypertension. Circ Res. 2004;94(8):1101-1108.

24. Hildebrand M. Pharmacokinetics and tolerability of oral iloprost in thromboangiitis obliterans patients. Eur J Clin Pharmacol. 1997;53(1):51-56.

25. Airo P, Rossi M, Scarsi M, Danieli E, Grottolo A, Zambruni A. Diseasemodifying effects of long-term cyclic iloprost therapy in systemic sclerosis. A retrospective analysis and comparison with a control group. Clin Exp Rheumatol. 2007;25(5):722-727.

26. Walmrath D, Schermuly R, Pilch J, Grimminger F, Seeger W. Effects of inhaled versus intravenous vasodilators in experimental pulmonary hypertension. Eur Respir J. 1997;10(5):1084-1092.

27. Schermuly RT, Pullamsetti SS, Breitenbach SC, Weissmann N, Ghofrani HA, Grimminger F, et al. Iloprost-induced desensitization of the prostacyclin receptor in isolated rabbit lungs. Respir Res. 2007;8:4.

28. Schermuly RT, Schulz A, Ghofrani HA, Breitenbach CS, Weissmann N, Hildebrand $\mathrm{M}$, et al. Comparison of pharmacokinetics and vasodilatory effect of nebulized and infused iloprost in experimental pulmonary hypertension: rapid tolerance development. J Aerosol Med. 2006;19(3):353-363.

29. Olschewski H, Ghofrani HA, Schmehl T, Winkler J, Wilkens H, Hoper MM, et al. Inhaled iloprost to treat severe pulmonary hypertension. An uncontrolled trial. German PPH Study Group. Ann Intern Med. 20;132(6):435-443.
30. Olschewski H, Walmrath D, Schermuly R, Ghofrani A, Grimminger F, Seeger W. Aerosolized prostacyclin and iloprost in severe pulmonary hypertension. Ann Intern Med. 1996;124(9):820-824.

31. McLaughlin VV, Oudiz RJ, Frost A, Tapson VF, Murali S, Channick RN, et al. Randomized study of adding inhaled iloprost to existing bosentan in pulmonary arterial hypertension. Am J Respir Crit Care Med. 2006;174(11):1257-1263.

32. Schermuly RT, Krupnik E, Tenor H, Schudt C, Weissmann N, Rose F, et al. Coaerosolization of phosphodiesterase inhibitors markedly enhances the pulmonary vasodilatory response to inhaled iloprost in experimental pulmonary hypertension. Maintenance of lung selectivity. Am J Respir Crit Care Med. 2001;164(9):1694-1700.

33. Schermuly RT, Leuchte H, Ghofrani HA, Weissmann N, Rose F, Kohstall M, et al. Zardaverine and aerosolised iloprost in a model of acute respiratory failure. Eur Respir J. 2003;22(2):342-347.

34. Ghofrani HA, Rose F, Schermuly RT, Olschewski H, Wiedemann R, Kreckel A, et al. Oral sildenafil as long-term adjunct therapy to inhaled iloprost in severe pulmonary arterial hypertension. J Am Coll Cardiol. 2003;42(1):158-164.

35. Schermuly RT, Ghofrani HA, Enke B, Weissmann N, Grimminger F, Seeger W, et al. Low-dose systemic phosphodiesterase inhibitors amplify the pulmonary vasodilatory response to inhaled prostacyclin in experimental pulmonary hypertension. Am J Respir Crit Care Med. 19;160(5 Pt 1):1500-1506.

36. Beghetti M, Berner M, Rimensberger PC. Long term inhalation of iloprost in a child with primary pulmonary hypertension: an alternative to continuous infusion. Heart. 2001;86(3):E10.

37. Beghetti M, Nicod L, Barazzone-Argiroffo C, Rimensberger PC. New combined treatments avoided transplantation in a child with severe pulmonary hypertension. Heart. 2004;90(2):154.

38. Tissieres P, Nicod L, Barazzone-Argiroffo C, Rimensberger PC, Beghetti M. Aerosolized iloprost as a bridge to lung transplantation in a patient with cystic fibrosis and pulmonary hypertension. Ann Thorac Surg. 2004;78(3):e48-e50.

39. Ivy DD, Doran AK, Smith KJ, Mallory GB Jr, Beghetti M, Barst RJ, et al. Short- and long-term effects of inhaled iloprost therapy in children with pulmonary arterial hypertension. J Am Coll Cardiol. 2008; 51(2):161-169.

40. Zwissler B, Kemming G, Habler o, Kleen M, Merkel M, Haller M, et al. Inhaled prostacyclin (PGI2) versus inhaled nitric oxide in adult respiratory distress syndrome. Am J Respir Crit Care Med. 1996; 154:1671-1677.

41. Olschewski H, Ghofrani HA, Walmrath D, Temmesfeld-Wollbruck B, Grimminger F, Seeger W. Recovery from circulatory shock in severe primary pulmonary hypertension $(\mathrm{PPH})$ with aerosolization of iloprost. Intensive Care Med. 1998;24(6):631-634.

42. Opitz CF, Wensel R, Bettmann M, Schaffarczyk R, Linscheid M, Hetzer R, et al. Assessment of the vasodilator response in primary pulmonary hypertension. Comparing prostacyclin and iloprost administered by either infusion or inhalation. Eur Heart J. 2003;24(4):356-365.

43. De Luca D, Zecca E, Piastra M, Romagnoli C. Iloprost as 'rescue' therapy for pulmonary hypertension of the neonate. Paediatr Anaesth. 2007;17(4):394-395.

44. Chotigeat U, Jaratwashirakul S. Inhaled iloprost for severe persistent pulmonary hypertension of the newborn. J Med Assoc Thai. 2007;90(1):167-170

45. Eifinger F, Sreeram N, Mehler K, Huenseler C, Kribs A, Roth B. Aerosolized iloprost in the treatment of pulmonary hypertension in extremely preterm infants: a pilot study. Klin Padiatr. 2008; 220(2):66-69.

46. Zwissler B, Rank N, Jaenicke U, Schürle B, Welte M, Reichart B, et al. Selective pulmonary vasodilation by inhaled prostacyclin in a newborn with congenital heart disease and cardiopulmonary bypass. Anesthesiology. 1995;82:1512-1516.

47. Sitbon O, Brenot F, Denjean A, Bergeron A, Parent F, Azarian R, et al. Inhaled nitric oxide as a screening vasodilator agent in primary pulmonary hypertension. Am J Respir Crit Care Med. 1995;151:384-389. 
48. Roberts JD Jr, Lang P, Bigatello LM, Vlahakes GJ, Zapol WM. Inhaled nitric oxide in congenital heart disease. Circulation. 1993; 87(2):447-453.

49. Hoeper MM, Olschewski H, Ghofrani HA, Wilkens H, Winkler J, Borst MM, et al. A comparison of the acute hemodynamic effects of inhaled nitric oxide and aerosolized iloprost in primary pulmonary hypertension. German PPH study group. J Am Coll Cardiol. 20;35(1): 176-182.

50. Berner M, Beghetti M, Spahr-Schopfer I, Oberhansli I, Friedli B. Inhaled nitric oxide to test the vasodilator capacity of the pulmonary vascular bed in children with long-standing pulmonary hypertension and congenital heart disease. Am J Cardiol. 1996;77(7):532-535.
51. Rimensberger PC, Spahr-Schopfer I, Berner M, Jaeggi E, Kalangos A, Friedli B, et al. Inhaled nitric oxide versus aerosolized iloprost in secondary pulmonary hypertension in children with congenital heart disease: vasodilator capacity and cellular mechanisms. Circulation. 2001;103(4):544-548.

52. Hallioglu O, Dilber E, Celiker A. Comparison of acute hemodynamic effects of aerosolized and intravenous iloprost in secondary pulmonary hypertension in children with congenital heart disease. Am J Cardiol. 2003;92(8):1007-1009. 
